\title{
Bacterial components plus vitamin D: The ultimate solution to the asthma (autoimmune disease) epidemic?
}

\section{Citation}

Weiss, Scott T. 2011. Bacterial components plus vitamin D: The ultimate solution to the asthma (autoimmune disease) epidemic? Journal of Allergy and Clinical Immunology 127, no. 5: 11281130. doi:10.1016/j.jaci.2011.02.025.

\section{Published Version}

doi:10.1016/j.jaci.2011.02.025

\section{Permanent link}

http://nrs.harvard.edu/urn-3:HUL.InstRepos:27002793

\section{Terms of Use}

This article was downloaded from Harvard University's DASH repository, and is made available under the terms and conditions applicable to Other Posted Material, as set forth at http:// nrs.harvard.edu/urn-3:HUL.InstRepos:dash.current.terms-of-use\#LAA

\section{Share Your Story}

The Harvard community has made this article openly available.

Please share how this access benefits you. Submit a story.

\section{Accessibility}




\title{
Bacterial Components plus vitamin D: The ultimate solution to the Asthma (autoimmune disease) Epidemic?
}

\author{
Scott T. Weiss, MD, MS \\ Professor of Medicine, Harvard Medical School \\ Director, Partners Center for Personalized Genetic Medicine, Partners Health Care \\ Associate Director, Channing Laboratory, Brigham and Women's Hospital
}

\section{Keywords}

asthma; microbiome; vitamin D

\begin{abstract}
In this issue of the Journal two review articles (one immunologic, one epidemiologic) draw attention to the human gut microbiome and its potential importance in human health and the development of allergic and autoimmune disease ${ }^{1,2}$. This editorial will try to synthesize the central messages of these reviews and outline the research directions in this emerging field. I will first review the data on the human microbiome, discuss factors that might influence gut bacterial colonization in humans, review the evidence that the microbiome is involved in allergic disease, and finally, consider the role of vitamin $\mathrm{D}$ in this process.
\end{abstract}

The gut microbiome is overwhelming in its size and its metabolic and antigenic complexity. There are $10^{14}$ bacteria in the gut, or 10 times more microbes in the human colon than there are cells in the human body. These bacteria belong to over 1000 species and have 3.3 million genes, over 150 times more genes than our own genome ${ }^{3}$. Culture alone is inadequate to identify the mostly anaerobic organisms of the gut, and bacterial sequencing must be used, in conjunction with culture, to definitively speciate, and hence identify, all of these organisms.

These bacteria interact with the host in a variety of ways. First, they interact with the gutassociated lymphoid tissue (GALT), the largest immune organ in the human body, and by their sheer size, they represent the major source of antigenic load to the human immune system. Second, these bacteria function as a metabolically active force to digest and modify the human diet. Third, our own genome interacts with, and helps determine, which bacteria are important to us ${ }^{4}$, thus providing a degree of complex gene environment interaction effect. One of the most striking examples of this later effect is that animal brain function and behavior can be influenced by the presence or absence of these commensual bacteria during development ${ }^{5}$.

C 2011 American Academy of Allergy, Asthma and Immunology. Published by Mosby, Inc. All rights reserved.

Corresponding author: Scott T Weiss, MD, MS, Channing Laboratory, 181 Longwood Avenue, Boston, MA 02115, 617-525-2278, scott.weiss@channing.harvard.edu.

Publisher's Disclaimer: This is a PDF file of an unedited manuscript that has been accepted for publication. As a service to our customers we are providing this early version of the manuscript. The manuscript will undergo copyediting, typesetting, and review of the resulting proof before it is published in its final citable form. Please note that during the production process errors may be discovered which could affect the content, and all legal disclaimers that apply to the journal pertain. 
The human gut flora is, quantitatively, the earliest, most diverse, and hence most important, postnatal source of microbial stimulation of the immune system in most species, including man, and hence the most likely determinant of normal tolerization ${ }^{6}$. Experiments in rodents suggest that bacterial gut colonization is essential for the development of oral tolerance and normal postnatal maturation of immune responses, ${ }^{7}$ including generation and/or expansion of T regulatory cells (Tregs) in peripheral tissues. ${ }^{8}$ Most of these "good bacteria" are anaerobes that are among the earliest life forms on the planet, having an evolutionary age of almost 6 billion years relative to our much more recent, 150,000 years. Dobzhansky has said that "nothing in biology makes sense except in light of evolution" and our coevolution with these anaerobic bacteria is critical to our understanding of how our immune system functions ${ }^{9}$. Ultimately how tolerization occurs, and how the gut microbiome relates to the skin and other microbiomes, such as the oral cavity, is currently unknown. However, Noverr and Huffnagle have postulated that the gut microbiome actually is the sensor for immune tolerance in the lung ${ }^{6}$ What does seem clear is that tolerization as an immune phenomenon is dominated by the gut flora because of the size of the GALT and the sheer magnitude of the gut microbiome antigenic mass. Initial colonizing bacteria can be a potent environment stimulus to the host, inducing genes in the host gut epithelium, and hence influencing host immune response. Thus good bacteria can potentially control, or prevent the growth of pathogenic bacteria, in part via immune system development and metabolic processes and by mechanisms as yet not understood. ${ }^{10}$.

The natural history of microbial colonization of the human gut and its relevance to disease is in its infancy. Existing studies in this area are few because of the novelty of the technology, high cost, and technical difficulty culturing anaerobes. Methodological issues such as small sample size, short duration of follow-up ${ }^{11}$, missing data on potentially relevant variables, and most importantly reliance on cultures alone, may miss relevant organisms, thus limiting what we know. ${ }^{12}$ Multiple clinical and molecular factors are likely to determine gut colonization in early fetal life: bacterial characteristics such as number, diversity, cell surface antigens, the presence or absence of pili, host mucosal cell properties such as cell surface receptors, and epidemiologic factors such as gestational age, mode of delivery, exposure to maternal fecal flora, maternal diet, fetal antibiotic use, and type of infant feeding, including probiotics. ${ }^{10,12,13}$

Of the multiple factors noted above, the maternal and fetal diet and pre and probiotics deserve some greater attention. At a CIBA symposium meeting in 1996 I was the first to suggest that dietary changes could be driving the allergy and autoimmune disease epidemic ${ }^{14}$. Food serves as an important substrate for bacteria digesting plant polysaccharides and hence producing short chain fatty acids and other nutrients for the bacteria and hence amplifying their influence immunologically ${ }^{15}$. This prebiotic function could potentially be exploited therapeutically if we knew which foods were promoting the "good" bacteria. Probiotics are cultures of normal gut flora organisms administered orally to influence immune function. ${ }^{16}$ Several studies, mostly with lactobacillus, have been performed ${ }^{17}$ including two small clinical trials ${ }^{18-20}$ The problem is that these studies are premature, since they beg the critical question of what are the relevant bacteria and their specific antigens that drive the putative immunoprotective effects. The evidence that lactobacilli are sufficient to do this is weak at best. Bacteroides fragilis would seem be a better bet, but unlike the mouse, a single bacterium is unlikely to be sufficient to achieve normal immune tolerization in the human.

Existing clinical studies performed in the presequencing era, suggest that the composition of the gut flora appears to differ between atopic and non-atopic infants; giving some credence to the hypothesis that reduced number and diversity of gut bacteria early in life lead to faulty tolerization and the development of allergic and other autoimmune disease. ${ }^{12,21-25} \mathrm{Ly}$ and 
coworkers review much of this work in greater detail ${ }^{2}$. In a small pilot study, we found that similar results to those studies cited above. We found that IL-10, an anti-inflammatory, Treg controlling cytokine modulated in part by vitamin $\mathrm{D}$, was increased in the cord blood of children whose mothers had a higher number of anaerobes in their gut. We went on to show that greater diversity of the infant fecal flora was protective for atopic dermatitis occurrence at 6 months of age. ${ }^{26} \mathrm{~A}$ recent review found that 14 of 17 studies in this area supported the findings that gut bacteria influenced the development of allergic disease ${ }^{27}$. These cited studies, including ours, are mostly of small sample size and, most importantly, lack robust, state of the art, gut microbiome assessment with both anaerobic culture and sequencing to maximally speciate the organisms. Finally, most studies do not adequately account for the confounding variables noted above. Suffice it to say, as the Ly review notes, we have no clear epidemiologic evidence as to the importance of specific bacterial species and whether number or diversity, or both, are the determining factors with regard to allergic diseases generally, or asthma specifically. This is in contrast to Crohn's disease where specific bacteria have been identified ${ }^{28}$.

How is vitamin D related to this process? We have previously reviewed in these pages the potential role of vitamin D deficiency in the development of allergic and autoimmune diseases and specifically their dramatic rise in prevalence in the last 50 years ${ }^{29}$. As we noted, vitamin D has clear structural effects on lung and airway development in utero ${ }^{29}$. It is worth recapitulating the immune portion of the argument here. Vitamin D is essential in the development and function of both T-regulatory cells $\mathrm{s}^{30,31}$ and dendritic cells ${ }^{32,33}$. It seems quite likely that Vitamin D is an important modulator of the signaling traffic between gut bacteria surface antigens via its effects on dendritic cells and the T-regs not just in humans, but in organisms as evolutionarily well preserved as the fly.

Experimental evidence suggests that biologically active form of vitamin D $(1,25$ $(\mathrm{OH})_{2}$ Vitamin $\mathrm{D}_{3}$ ) influences the process by which immune cells acquire signaling molecules that enable them to migrate to normal extra lymphoid tissue sites, as well as sites of inflammation. The gastrointestinal mucosa, as the main body surface exposed to environmental antigens (specifically gut bacteria), has well-described tissue-specific adhesion and chemo attractant "homing" receptors. ${ }^{34}$ Vitamin D can block or down regulate gut homing of both normal immune and inflammatory cells. For example, vitamin D receptor (VDR) gene expression is required for Dendritic and T cells and other immune cells to control inflammation in the IL-10 knockout mouse model. ${ }^{35}$ By up-regulating normal immune function of T-regs, specifically through il10 and TGFB1, vitamin D can promote normal tolerization. Conversely, reduced vitamin $\mathrm{D}$, or reduced number and diversity of gut bacteria, or both, will promote inflammation that may disrupt the mucosal barrier, and promote food and other allergen sensitization or abnormal tolerization. Thus pathogenic and commensal gut bacteria may play opposing roles in allergy development, and these roles may be modulated by the VDR, other host genes, and by vitamin D itself. It is also possible that independent of its immune effects, vitamin D has a direct effect on gut bacterial flora to increase or decrease the number of specific species of bacteria or species diversity. These complex effects are synthesized in figure 1. Given the current IOM report on vitamin D dosage, it is worth considering what level of vitamin D would provide immunoprotection for the development of allergic and autoimmune disease (IOM report). While this is currently unknown, it would seem that higher doses than those currently recommended by the IOM report for bone health will almost certainly be necessary. Further research is needed in this area.

It is worth noting that the microbiome/vitamin D hypothesis to explain the origins of the autoimmune disease epidemic fits the facts far better than the hygiene hypothesis ${ }^{29}$. The hygiene hypothesis never could explain the rise in Th1 autoimmune disease, in addition to 
asthma and allergy, and the high rates of asthma, and allergy among the urban poor in the US. Both phenomena are easily explained by vitamin D deficiency. The strong link between the microbiome and vitamin D closes the loop by providing a plausible immunologic substrate for vitamin D effects on normal tolerization. We have clear evidence for dramatic changes in vitamin D levels over the 50 year period that has seen the dramatic increase in autoimmune disease; what we don't know is what has happened to the gut microbiome during that period. Current clinical trials in the US and Denmark will test whether giving vitamin D to pregnant women will prevent asthma in their offspring (Vitamin D Antenatal Asthma Reduction Trial, VDAART, U01 HL091528, ClinicalTrials.gov: NCT00856947) although this is unlikely to be the whole story as this trial will not test the effect of postnatal sufficiency on asthma risk. A funded ancillary study will allow an exploration of the relative importance of vitamin $\mathrm{D}$ and the gut flora on disease risk.

Identification of the "good bacteria" in the human gut microbiome is of primary scientific importance in understanding allergic diseases. This will not be a trivial exercise given the size and diversity of the gut microbiome. If this task can be accomplished, then it is conceivable that in the not too distant future we will prevent asthma, food allergies, atopic dermatitis, allergic rhinitis, and other autoimmune diseases like Crohn's disease, type 1 Diabetes Mellitus, and Multiple Sclerosis with a cocktail of anaerobic bacterial antigens, dietary constituents, or the bacteria themselves (prebiotics and probiotics) in combination with vitamin $\mathrm{D}$, administered orally to both pregnant women and their offspring, but first we need to find the protective bacterial species, identify their antigens, understand more clearly how vitamin D modulates the signaling from gut bacteria to dendritic cells and to T-regs, and what dose of vitamin D is necessary. This is an exciting time for asthma research, and for autoimmune disease research generally, and the gut microbiome will be an important extension of genomics to the environment. Elucidating its influence on the development of allergic disease is going to certainly contribute to this excitement.

\section{References}

1. McLoughlin R, Mills KHG. Influence of gastrointestinal commensal bacteria on the immune responses that mediate allergy and asthma. 2011 Submitted.

2. Ly NP, Litonjua AA, Gold D, Celedon JC. Gut microbiota, probiotics, vitamin D, asthma, and obesity. 2011 Submitted.

3. Zhu B, Wang X, Li L. Human gut microbiome: the second genome of human body. Protein Cell. 2010 Aug.(1):718-725. [PubMed: 21203913]

4. Benson A, Kelly S, Legge R, et al. Individuality in gut microbiota composition is a complex polygenic trait shaped by multiple environmental and host genetic factors. PNAS. 2010; 107:18933-18938. [PubMed: 20937875]

5. Diaz-Heijtz R, Wang S, Anuar F, et al. Normal gut microbiota modulates brain development and behavior. PNAS. 2011 Published online:2011.

6. Noverr M, Huffnagle G. Does the microbiota regulate immune responses outside the gut? Trends in Microbiology. 2004; 12:562-568. [PubMed: 15539116]

7. Rask C, Evertsson S, Telemo E, Wold AE. A Full Flora, but not Monocolonization by Escherichia coli or Lactobacilli, Supports Tolerogenic Processing of a Fed Antigen. Scand J Immunol. 2005; 61:529-535. [PubMed: 15963047]

8. Strauch UG, Obermeier F, Grunwald N, et al. Influence of intestinal bacteria on induction of regulatory T-cells: lessons from a transfer model of colitis. Gut. 2005

9. Dobzhansky T. Biology, Molecular and Organismic. American Zoologist. 1964; 4:443-452. [PubMed: 14223586]

10. Guarner J, de Leon-Bojorge B, Lopez-Corella E, et al. Intestinal intussusception associated with adenovirus infection in Mexican children. Am J Clin Pathol. 2003; 120:845-850. [PubMed: 14671973] 
11. Harmsen HJ, Wildeboer-Veloo AC, Raangs GC, et al. Analysis of intestinal flora development in breast-fed and formula-fed infants by using molecular identification and detection methods. $\mathrm{J}$ Pediatr Gastroenterol Nutr. 2000; 30:61-67. [PubMed: 10630441]

12. Adlerberth I, Strachan DP, Matricardi PM, et al. Gut microbiota and development of atopic eczema in 3 European birth cohorts. J Allergy Clin Immunol. 2007; 120:343-350. [PubMed: 17604093]

13. Edwards CA, Parrett AM. Intestinal flora during the first months of life: new perspectives. $\mathrm{Br} \mathbf{J}$ Nutr. 2002; 88 Suppl 1:S11-S18. [PubMed: 12215177]

14. Weiss, ST. Diet as a risk factor for asthma. In: Barnes, PJ.; Grunstein, MM.; Leff, AR.; Woolcock, AJ., editors. CIBA Found Symp; Asthma; Philadelphia. Lippincott-Raven Publishers; 1997. p. 244-247.

15. Maslowski K, Mackay C. Diet, gut microbiota and immune responses. Nature Immunology. 2011; 12:5-9. [PubMed: 21169997]

16. Borriello SP, Hammes WP, Holzapfel W, et al. Safety of probiotics that contain lactobacilli or bifidobacteria. Clin Infect Dis. 2003; 36:775-780. [PubMed: 12627362]

17. Kalliomaki M, Salminen S, Poussa T, Arvilommi H, Isolauri E. Probiotics and prevention of atopic disease: 4-year follow-up of a randomised placebo-controlled trial. Lancet. 2003; 361:1869-1871. [PubMed: 12788576]

18. Isolauri E, Arvola T, Sutas Y, Moilanen E, Salminen S. Probiotics in the management of atopic eczema. Clin Exp Allergy. 2000; 30:1604-1610. [PubMed: 11069570]

19. Weston S, Halbert AR, Richmond P, Prescott SL. Effects of probiotics on atopic dermatitis: a randomised controlled trial. Arch Dis Child. 2005

20. Prescott SL, Dunstan JA, Hale J, et al. Clinical effects of probiotics are associated with increased interferon-gamma responses in very young children with atopic dermatitis. Clin Exp Allergy. 2005; 35:1557-1564. [PubMed: 16393321]

21. Sepp E, Julge K, Vasar M, Naaber P, Bjorksten B, Mikelsaar M. Intestinal microflora of Estonian and Swedish infants. Acta Paediatr. 1997; 86:956-961. [PubMed: 9343275]

22. Bjorksten B, Naaber P, Sepp E, Mikelsaar M. The intestinal microflora in allergic Estonian and Swedish 2-year-old children. Clin Exp Allergy. 1999; 29:342-346. [PubMed: 10202341]

23. Bottcher MF, Nordin EK, Sandin A, Midtvedt T, Bjorksten B. Microflora-associated characteristics in faeces from allergic and nonallergic infants. Clin Exp Allergy. 2000; 30:1590 1596. [PubMed: 11069568]

24. Kalliomaki M, Kirjavainen P, Eerola E, Kero P, Salminen S, Isolauri E. Distinct patterns of neonatal gut microflora in infants in whom atopy was and was not developing. J Allergy Clin Immunol. 2001; 107:129-134. [PubMed: 11150002]

25. Penders J, Thijs C, van den Brandt PA, et al. Gut microbiota composition and development of atopic manifestations in infancy: the KOALA Birth Cohort Study. Gut. 2007; 56:661-667. [PubMed: 17047098]

26. Forno E, Onderdonk AB, McCracken J, et al. Diversity of the gut microbiota and eczema in early life. Clin Mol Allergy. 2008 Sep.22:11. [PubMed: 18808715]

27. Penders J, Stobberingh EE, Van den Brandt PA, Thijs C. The role of the intestinal microbiota in the development of atopic disorders. Allergy. 2007; 62:1223-1236. [PubMed: 17711557]

28. Cadwell K, Patel K, Maloney N, et al. VIrus-plus-susceptibility gene interaction determines Crohn's disease gene Atg 16L1 phenotypes in intestine. Cell. 2010; 141:1135-1145. [PubMed: 20602997]

29. Litonjua A, Weiss S. Is vitamin D deficiency to blame for the asthma epidemic? J Allergy Clin Immunol. 2007 Nov.(120):1031-1035. [PubMed: 17919705]

30. Taher YA, van Esch BCAM, Hofman GA, Henricks PAJ, van Oosterhout AJ. 1 alpha, 25dihydroxyvitamin D3 potentiates the beneficial effects of allergen immunotherapy in a mouse model of allergic asthma: role for IL-10 and TGF-B1. The Journal of Immunology. 2008; 180:5211-5221. [PubMed: 18390702]

31. Xystrakis E, Kusumakar S, Boswell S, et al. Reversing the defective induction on IL-10-secreting regulatory $\mathrm{T}$ cells in glucocorticoid-resistant asthma patients. The Journal of clinical Investigation. 2006; 116:146-155. [PubMed: 16341266] 
32. Adorini L, Giarratana N, Penna G. Pharmacological induction of tolerogenic dendritic cells and regulatory T cells. Seminars in Immunology. 2004; 16:127-134. [PubMed: 15036236]

33. Griffin MD, Xing N, Kumar R. Gene expression profiles in dendritic cells conditioned by 1alpha, 25-dihydroxyvitamin D3 analog. J Steroid Biochem Mol Biol. 2004; 89-90:443-448.

34. Moro J, Iwata M, von Andriano U. Vitamin effects on the immune system: vitamins A and D take centre stage. Nat Rev Immunol. 2008; 8:685-698. [PubMed: 19172691]

35. Froicu M, Zhu Y, Cantorna M. Vitamin D receptor is required to control gastrointestinal immunity in IL-10 knockout mice. Immunology. 2006; 117:310-318. [PubMed: 16476050] 


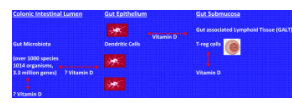

Figure 1. Vitamin D May Determine How Gut Flora Interacts with the Immune System Vitamin D may directly influence the number or diversity of the Gut microbiota. It does influence dendritic cell antigen processing but how it does this with gut bacteria is unknown. It controls immune trafficking between dendritic cells and T-reg cells. Finally, through IL10, and TGFB1, it modulates T-ref function through all three effector arms of the adaptive immune response $\mathrm{TH}_{1}, \mathrm{TH}_{2}$, and $\mathrm{TH}_{17}$. 